\title{
Of Luck Both Epistemic and Moral in Questions of Doping and Non-Doping
}

\author{
Kenneth William Kirkwood \\ (Western University; London; Ontario; kkirkwo2@uwo.ca) \\ ORCID: 0000-0001-9615-4650
}

\section{Introduction}

"An athlete, whom I will call Dave, approached me for a conversation during my office hours. During our meeting, he disclosed that he had thoughtfully and deliberately instituted a doping plan to boost his chances of athletic success in the following football season. He detailed for me all of the research he had done to determine the optimal cocktail of drugs to take to maximize the benefit to himself. He recounted to me his dosages and timing, along with training schedule, training methods and how he had felt the drugs at work in his body. At one point after several months and several cycles of drug dosages, the young man and several other teammates were drug-tested by the governing body. Sometime after the test, one teammate went to the coach and confessed that he had been on prohibited drugs and was likely to 'come back positive.' The coach then spoke with all the tested athletes, and soon discovered more than half of them were doping and likely to be exposed for

it when the test results were made public. Dave also confessed to his coach about his drug use, and the coach said that they would deal with the issue when the results became known. When the results were publicized, the athletes who had confessed their doping to the coach were named, but the young man I spoke to was not named. Everyone Dave confided in was confused by this at the time, because for all his drug use, the young man had not taken any drugs to mask his prohibited drug use, but rather had counted on not being tested. So, it was unclear to everyone at that time why he didn't test positive. On the heels of these tests, the drug supplier that Dave had dealt with was arrested for numerous drug offenses, and it became known through the police that he had been selling 'counterfeit' performance-enhancing drugs which contained no active ergogenic or anabolic agents. His question to me was: is he as "morally bad" as his teammates?" 
(Kirkwood 2014, p.57).

In reflecting on this passage, it seemed to be an exemplar case of moral luck. Further contemplation revealed some arguments to the validity of the challenge that epistemic luck poses to the existence of moral luck. The purpose of this paper is to examine Dave's case, and doping more generally, in light of moral and the more compelling argument from epistemic luck. This paper takes the approach that luck does not change the moral status of an act, simply our position from which we can assess the moral content of the actor - what Latus (2000) calls the "epistemic argument."

\section{Moral Luck}

When we use the term 'luck' in common parlance, we typically mean that one is lucky when good things happen to that person. The good things are in no discernable way a credit to the agent, as they are in no way within his or her control, or a product of any personal effort or virtue (Statman 1991). The converse is equally true: a person is unlucky if he or she suffers bad fortune for no apparent causal conduct of his or her own.

Because of the primacy of duty in his deontological thought, Kant (1785/1998) specified that luck played no role in morality. This makes sense in light of Kant, as luck speaks to outcomes, rather than fidelity. One is 'morally lucky' when factors outside of one's control minimize or eliminate the weight of moral judgment otherwise due to the agent. When things beyond our control reduce the harm, we may have created with or without intent, we are judged differently than in the hypothetical instance wherein we competently carried out our actions. Hurka (1994) describes it as often coming down to the difference between harmless negligence and harmful negligence. Moral luck seems to be an indisputable staple of our moral experiences. It doesn't seem to be an implausible assumption that all of us have enjoyed moments wherein we have avoided harsher moral assessment as our intentions or negligence failed to produce the outcomes they very well could have, and by extension, spared us from the moral judgment that accompanies that full outcome. This becomes a problem when we consider the "standard view" of responsibility which sees people as responsible only for what they controlled in the course of morally appraisable actions (Coeckelbergh 2010). When luck occurs it runs counter to the goals of justice as it undermines the standard view.

Nagel (1993) subdivides moral luck into a quartet of kinds, resultant, circumstantial, constitutive and causal, and of the four we are most interested in resultant moral luck. Resultant luck is good fortune in terms of outcome. In Dave's case, he had the same intentions, similar methods, and the same desires as his teammates who tested positive. Caeteris paribus, Dave's differing biochemical make-up as assessed by the drug test subjects him to a different moral assessment than his teammates and makes him the beneficiary of resultant moral luck. What is relevant to us here in discussing Dave's case is what Nagel (1979) termed "the trap" between intuition and fact. Nagel describes the 
intuition as the notion that luck shouldn't play a role in mitigating moral responsibility it seems wrong to assign luck a role in differentiating moral outcomes. The "fact," as Nagel sees it, is the realization spoken to earlier; that luck does exactly what our intuitions say it shouldn't, it makes a significant moral difference. ${ }^{1}$ In Dave's case, it was resultant moral luck that made the difference between himself and his like-minded teammates, but still leaves us with our intuition that such as state of affairs shouldn't be. Dave did everything to dope, except dope. What should we make of Nagel's trap in this instance?

Sensibly, the trap is typically attacked on one of its two fronts: either the intuition or the fact is wrong. Walker (1993) challenges the intuition by suggesting that the commonly understood sense of moral agency is mistaken. One could summarize these arguments to say 'if we better understood how people actually acted, we wouldn't worry about the problematic effects of luck.' On the second front, the assailants of Nagel's fact generally deny attribute the difference made by moral luck is one of epistemology rather than morality. This is the impetus for the denial of Nagel's fact from the position of epistemic luck.

\section{Epistemic Luck}

The epistemic argument asserts that what changes in the occurrence of moral luck is not related to a moral variable in the sense of the innate moral worth of the actor ${ }^{2}$, but rather changes our position to judge the moral standing of the actor. When an agent carries out an immoral act, their success often brings forth evidence of their actions and intentions to judge them by. ${ }^{3}$ It isn't always the case that failed attempts offer us the same epistemic position from which to judge. On those occasions where we can know the intentions of a failed perpetrator, then we could justify equal treatment with those who succeed. The difference between the detected and undetected wrongdoer isn't the immunity from moral judgment that we grant the undetected actor, but rather our state of unawareness prevents us from accessing the empirical and descriptive components of evaluating moral responsibilities and conduct of the actor. In our specific case, resultant luck affects the basis available to us when we judge agents, but does not affect what those agents deserve. Statman sums it neatly when he notes:

... luck does not affect one's deserts but only our knowledge of them. Moral bad luck is not luck in one's moral standing being hurt, but bad luck in one's character becoming transparent to others (Statman 1993, 17).

1 Nagel refers to this as fact, but it seems to be a trap between intuitions. This point of clarification doesn't take away from Nagel's point.

2 To imagine what a moral agent is, I use Rachels' minimal conception of morality and imagine a person adherent to it (see Rachels 1999).

3 For example, when one breaks a promise or uses deceit, there is a witness who suffered from infidelity or deception who can articulate the nature of the moral offense. 
In the resultant-luck case of Dave and his less fortunate teammates, the epistemic argument poses that there is no moral difference between them. There is an epistemic difference in that Dave's teammates have given us a clear indication of their moral deficiencies, Dave was simply lucky to avoid detection and subsequent honest assessment of this moral standing - but not lucky in Nagel's sense of moral luck.

\section{Critique: Is It Luck or Reductionism?}

Schinkel (2009) finds fault with epistemic luck as he finds it to be a reductio ad absurdum to claim that all cases of moral luck are really just cases of knowing, and deems epistemic luck to be a case of epistemic reductionism. The reduction here in Schinkel's reading, is the reducibility of actions to intentions. His claim rests on two key aspects: first, he finds that epistemic reductionism offers an implausible separation of judgments of intentions and judgments of actions. Secondly, he sees epistemic reductionism to focus on solitary actions retrospectively and failing to capture the nature of the risks a morally unlucky agent might have taken.

On the first point, epistemic reductionism focuses in some part on desert, and takes its cue from Feinberg's (1970) notion of the concept as derived from some moral feature of the agent. Desert, as epistemic luck theorists such as Richards (1993) hold it, see as the product of actions we perform or attributes we possess. Contra Schinkel, it isn't a grand departure from a conceivable formulation of epistemic luck to state that desert can also be based on positive attributes in evident development. In our present case, if Dave offers contrition for his attempted doping, that factors into his moral appraisability. ${ }^{4}$ Our knowledge of him is different when we know of him as an unapologetic recidivist as opposed to a genuine penitent.

This leads us to the second point, wherein the undertaking of risk can be misrepresented as reckless and lend itself to a stunted historical judgment of the actor. Here Schinkel has corrected identified a descriptive feature of the arguments for epistemic luck - many scholars fail to see the moral character as a longitudinal developmental feature. There is nothing present in the literature that prevents such an interpretation. While the view is often cast as passing judgment in situ of disclosure, there is nothing to suggest that such judgments are final or ahistorical. Indeed, there is nothing in the position taken by many advocates of epistemic luck to suggest that epistemic luck theorists eschew complexities of character or deep contingencies when considering moral judgments.

A final consideration is the construction of epistemology that Schinkel deploys here is somewhat misleading. Knowledge about objects or less-sentient creatures can be objectively obtained and thereby be 'true' in the sense that they are reliably reproduced $a d$ infinitum. Knowledge about human beings and their agency is notably unlike the qualities

4 Which he did not offer about his actions - only regret about the fact that he enjoyed luck in nondetection while his teammates did not. 
of objects or lower life-forms. The relevant facts about a person's moral life, inclusive of his contemplations, intentions, and commitments, not merely his actions, is a profoundly contingent epistemological venture. Only in fictitious realms is the perfect foreknowledge ${ }^{5}$ of human moral agency possible. For the rest of us, we are stuck in state of skepticism (Statman 1991) wherein we make 'best possible' moral judgments of others, realizing that it is subject to revision pending further developments. The reduction Schinkel decries is not, as typical critiques of reductionist arguments address, an oversimplification of cause or relation. Epistemic luck recognizes the logical necessity that a fair assessment of one's moral status would depend on robust understandings of the elements of what it means to be a moral agent. ${ }^{6}$

\section{Epistemic Luck and the Doping Phenomenon}

Knowledge of doping is one of the key issues in academic debates about doping presently. The irrefutable, but somewhat regressive, rejoinder one might hear in debates about doping is that 'no one' knows how many athletes in any sport actually take these drugs (Dilger, Frick \& Tolsdorf 2007). It reflects a common intuition amongst those who think about sport, and it matters to people's moral view of the institution of sport and the agent-athletes what the 'truth' is about doping in sport. The effect of that knowledge, if some reliable aspect of it was ever to appear in public, would inform the moral judgments of athletes who engage in it, but also of the sports in which they compete. ${ }^{7}$ It is also a feature which encourages certain sports leagues to obfuscate the issue of drugs in their sports, to delay or hide from judgments of their institutions over the issue of doping. The very utility of deception on the issue points to the matter of the epistemic position, and also how the preponderance of circumstantial and hearsay evidence that occupies our knowledge about doping in sport presently can create negative moral predispositions in people who desire to know and to have the opportunity to fairly judge this matter of what is likely to be of deep personal concern to them.

A good stroke of epistemic luck would be valuable for high-level sport, or at least for those who see moral value in high-level performance. Currently, there is a cognitive dissonance between our appreciation for impressive physical performance and a desire

5 By "perfect foreknowledge" I intend a meaning such as 'that what is anticipated is equal to what will be experienced.' The quality often ascribed to deities (see Zagzebski 1991).

6 By counterexample, we can consider the hypothetical case of a highly moral person who would want full disclosure for the purposes of judgment, for fear that she would suffer from bad epistemic luck in that her good intentions and deeds would go underestimated (for more, please see Rosebury 1995).

7 A current example is the anticipated testimony of former Tour de France champion Lance Armstrong against the UCI and its alleged participation in, and support of, doping in cycling. He could disclose information of the quantity and quality sufficient to fundamentally alter a moral judgment of both the individual cyclists who doped and the sporting and anti-doping organizations that pursued them. 
for drug-free achievement. ${ }^{8}$ It would seem that high-level sports have enjoyed a great deal of anonymity in matters of doping. Be they user-athletes or sporting leagues and federations engaged in subterfuge against their own doping-control policies, the conduct around matters of doping have been duplicitous and have allowed skepticism to dominate a field in which considered moral judgment belongs. ${ }^{9}$

\section{Conclusion}

One can imagine that athletes in certain sports tire of the questions about how many of their fellow athletes are taking performance-enhancing drugs. It is also certain that some have answered "none" only to be proven wrong at subsequent doping control enforcements. In Dave's case he has, with the exception of those in whom he confided, avoided detection of his behavior. This is not to say that he enjoys a different moral standing than his publicly-shamed teammates, but rather his standing has only suffered in the eyes of those in whom he confided. His intentions and desires were to cheat - to engage in deceit, favouring his own advantage over others', and to steal victory from those who would have earned it according to their mutual understanding. His question to me about his moral status in relation to his exposed colleagues reflects the spirit of the platitude "two wrongs don't make a right." In this case, two wrongs; the efforts and intention to cheat, and his drug suppliers' deceit fail to make a 'right,' nor mollify our judgments to a state of moral indifference.

\section{References}

Carstairs C. 2003. "The Wide World of Doping: Drug Scandals, Natural Bodies, and the Business of Sports Entertainment," Addiction Research and Theory 11(4):263-281.

Coeckelbergh M. 2010. "Criminals or Patients? Towards a Tragic Conception of Moral and Legal Responsibility," Criminal Law and Philosophy 4:233-244.

Concepcion D. 2002. "Moral Luck, Control, and the Bases of Desert," The Journal of Value Inquiry 36:455-461.

8 This assumes that a sizable number of people hold the contradictory desires for witnessing drug-free high performance. Others have claimed that questions about doping have become lingua franca for sporting fans and are an important part of the dominant place of sport in everyday life (see Carstairs 2003). Others have suggested that the result of dividing major sporting events, such as the Olympics, into doped and 'drug-free' divisions would bare disappointing results for the 'clean' spectacle (see Kirkwood 2009, 13).

9 This is a troubling sociological feature of the phenomenon of epistemic luck; those who would draw joy, inspiration or other benefits from witnessing athletic excellence are prevented from doing so by a 'normal nihilism' that clouds sport with questions about 'if' performances worthy of admiration are truly that. 
Dilger A., Frick B., \& Tolsdorf F. 2007. "Are Athletes Doped? Some Theoretical Arguments and Empirical Evidence," Contemporary Economic Policy 25:604-615.

Feinberg J. 1970. “Justice and Personal Desert," in J. Feinberg (Ed.), Doing and Deserving (pp. 221-250). Princeton, NJ: Princeton University Press.

Hurka T. 1994. Principles: Short Essays on Ethics. Toronto, ON: Harcourt Brace.

Kant I. 1998. Groundwork of the Metaphysics of Morals, M. Gregor (Ed. and Transl.). Cambridge, MA: Cambridge University Press.

Kirkwood K. 2009. A Modest Proposal: The Ethics of Supervised Doping at the Olympics. Saarbrücken, DE: Lambert Academic Press.

Kirkwood K. 2014. “What do You Mean I Wasn't Cheating? Testing the Concept of Cheating through a Case of Accidental Doping," Sport, Ethics and Philosophy 8(1):57-64.

Latus A. 2000. "Moral and Epistemic Luck," Journal of Philosophical Research 25:149-172. Nagel T. 1979. Mortal Questions. New York: Cambridge University Press.

Nagel T. 1993. “Moral Luck,” in D. Statman (Ed.), Moral Luck (pp. 57-71). Albany, NY: State University of New York Press.

Pritchard D. 2006. "Moral and Epistemological Luck," Metaphilosophy 37(1):1-25.

Rachels J. 1999. The Elements of Moral Philosophy ( $3^{\text {rd }}$ ed.). New York: McGraw-Hill.

Rescher N. 1995. Luck: The Brilliant Randomness of Everyday Life. New York: Farrar, Straus and Giroux.

Richards N. 1993. “Luck and Desert," in D. Statman (Ed.), Moral Luck (pp. 167-180). Albany, NY: State University of New York Press.

Rosebury B. 1995. “Moral Responsibility and 'Moral Luck',' Philosophical Review 104 (4):499-524.

Schinkel A. 2009. "The Problem of Moral Luck: An Argument Against its Epistemic Reduction," Ethical Theory and Moral Practice 12:267-277.

Statman D. 1991. "Moral and Epistemological Luck," Ratio IV:146-156.

Statman D. 1993. "Introduction to Moral Luck," in D. Statman (Ed.), Moral Luck (pp. 1-25). Albany, NY: State University of New York Press.

Walker M. U. 1993. "Moral Luck and the Virtues of Impure Agency," in D. Statman (Ed.), Moral Luck (pp. 235-250). Albany, NY: State University of New York Press.

Zagzebski L. T. 1991. The Dilemma of Freedom and Foreknowledge. London, UK: Oxford University Press. 
Kenneth William Kirkwood (London, Ontario)

Of Luck Both Epistemic and Moral in Questions of Doping and Non-Doping

Abstract: This article is a case study of a question of possible doping and how our insights into our moral judgements about doping are subject to considerations of both moral, but more presciently, epistemic luck. The eternal ambiguity surrounding the prevalence of doping, and its impact on high-level sport make this question entirely relevant for our discussions about the ethics of performanceenhancement in sport.

Keywords: doping; ethics; sport; moral luck; epistemic luck; case study.

Ethics in Progress (ISSN 2084-9257). Vol. 11 (2020). No. 1, Art. \#4, pp. 77-84. Creative Commons BY-SA 4.0

DOI:10.14746/eip.2020.1.4 